\title{
Effect of water hyacinth on distribution of sulphate-reducing bacteria in sediments of Lake Victoria
}

\author{
Fredrick J Muyodi ${ }^{* *}$, Mugassa ST Rubindamayugi ${ }^{2}$, Adelaide K Semesi ${ }^{2}$ \\ ${ }^{1}$ Department of Zoology, Faculty of Science, Makerere University, PO Box 7062, Kampala, Uganda \\ ${ }^{2}$ Applied Microbiology Unit, Department of Botany, Faculty of Science, University of Dar es Salaam, PO Box 35060, \\ Dar es Salaam, Tanzania
}

\begin{abstract}
The effect of the water hyacinth, Eichhornia crassipes (Mart.) Solms-Laub, on the distribution of populations of sulphate-reducing bacteria (SRB) in sediments from various stations on the shores of Lake Victoria around Mwanza Municipality, Tanzania, was studied. Lactate-utilising SRB were observed to be the dominant species in sediments covered by the water hyacinth and at the Mirongo River mouth while acetate-utilising SRB dominated in the offshore open water sediments. Sediments from offshore open waters had the lowest most probable numbers (MPNs) for all the SRB types investigated, more than 100 times less that observed in areas covered by the water hyacinth and the Mirongo River mouth. Lactate-utilising SRB were almost absent in sediments from offshore open waters. A positive correlation between the total populations of SRB and nutrients in sediments was observed. Results showed that sulphate concentration was very high in sediments underneath the water hyacinth at the lakeshore but was minimal in sediments from offshore open waters. It is suggested that water hyacinth decomposition formed lactate, which supported large populations of lactate-utilising SRB.
\end{abstract}

Keywords: acetate, Eichhornia crassipes, formate, hydrogen sulphide, lactate, methanogen, sulphate-reducing bacteria (SRB)

\section{Introduction}

Sulphate is used as a terminal electron acceptor under anoxic conditions by a heterogeEHneous assemblage of bacteria known as the sulphate-reducing bacteria (SRB). These bacteria utilise organic acids, fatty acids, alcohol, and hydrogen as electron donors. SRB have been placed into two broad physiological subgroups (Brock, 1997). The first subgroup consisting of genera Desulfovibrio, Desulfomonas, Desulfotomaculum, and Desulfobolus, utilise lactate, pyruvate, ethanol, or certain fatty acids as carbon and energy sources, reducing sulphate to hydrogen sulphide. SRB from the other subgroup consisting of Desulfobacter, Desulfococcus, Desulfosarcina and Desulfonema, specialise in oxidation of fatty acids, particularly acetate, reducing sulphate to sulphide. SRB are universally distributed in marine and freshwater sediments (King and Garry, 1999) and are now reported to be distributed in microbial mats including cyanobacterial mats (Van Gemerden, 1993; Teske et al., 1998; Minz et al., 1999). SRB have also been isolated from soil (IIori et al., 1999). Many of the SRB that have been isolated and described so far are mesophylic, nonsporing anaerobes (Widdel and Bak, 1991; Standard Methods, 1995). Distribution of SRB in hot water supply systems and hydrothermal vents has also been reported (Rozanova and Entaltseva, 1999).

Competition for electron donors between SRB and methanogens has received considerable attention (Widdel and Bak, 1991). SRB have a higher affinity (lower $\mathrm{K}_{m}$ ) for the major precursors, hydro-

\footnotetext{
* To whom all correspondence should be addressed.

政+256 (041) 531902; fax:+256 (041) 531061;

e-mail: fmuyodi@zoology.mak.ac.ug

Received 16 January 2004; accepted in revised form 5 March 2004.
}

gen and acetate than methanogens (Holmer and Kristensen, 1994). The $\mathrm{K}_{m}$ value for hydrogen is about $1 \mu \mathrm{M}$ for SRB and $6 \mu \mathrm{M}$ for methanogens, and for acetate the $\mathrm{K}_{m}$ values for SRB and methanogens are $200 \mu \mathrm{M}$ and $3 \mathrm{mM}$, respectively (Schonheit et al., 1982). This enables SRB to maintain the pool of these substrates at concentrations too low for methanogens, when sulphate is not limiting. When utilising $\mathrm{H}_{2}$ as the electron donor, Desulfovibrio species have a high maximum growth rate $\left(\mathrm{m}_{\max }=0.23 \mathrm{~h}^{-1}\right)$ and a low half-saturation constant $\left(\mathrm{K}_{\mathrm{s}}=3.3 \mu \mathrm{M}\right)$. The $\mathrm{m}_{\max } / \mathrm{K}_{\mathrm{s}}$ value indicates that the effectiveness of substrate utilisation is higher than that of $\mathrm{H}_{2}$-consuming methanogenic organisms (Widdel and Bak, 1991). This probably explains why SRB outcompete methanogenic bacteria for substrates even in very low concentrations.

Waters of Lake Victoria are exposed to high organic loading from decaying weed, sewage and municipal waste discharge (Merinyo, 1990; Hecky et al., 1995; Ogutu-Ohwayo et al., 1997; Kansiime and Nalubega, 1999). Due to a lack of complete mixing of the water column by strong waves, especially in areas infested by the alien weed, water hyacinth, Eichhornia crassipes (Mart.) Solms-Laub (Pontederiaceae), organic levels increase and are restricted to surface layers of the sediments, where sulphate reduction activity attains exceptionally high rates. Accumulation of substrates, e.g. acetate, for the SRB has been reported to take place under such circumstances despite high mineralisation rates (Holmer and Kristensen, 1994) as the amount of substrates produced cannot all be utilised by micro-organisms. The distribution of different species of SRB in sediment broadly corresponds to the distribution of different substrates needed for the sulphate reduction process and the concentration of substrates present (Parkes et al., 1993). SRB can have a considerable effect on their environment, because their growth is coupled to the production of large amounts of hydrogen sulphide. This activity is important in the removal of 
acidic, oxidised forms of sulphur from the environment and in the immobilisation of toxic metal ions, as present in acid mine drainage effluents. However, despite the above environment-restoring properties, SRB are considered a nuisance in many environments due to the odour, toxicity and metal-corroding properties of their respiratory end product (IIori et al., 1999; King and Garry, 1999).

Sulphate is a limiting factor in most of the freshwater sediments. Anoxic sediments of freshwater lakes where sulphate is available have been observed to be habitats for SRB (Teske et al., 1998). Sulphate reducers have also been isolated from rice paddies and in anaerobic digesters of sewage plants (Widdel and Bak, 1991; Wind et al., 1999). Significant sulphate reduction activities and SRB cells have been observed in the upper oxic zones of fresh and marine water sediments (Teske et al., 1998). The aim of the present study was to investigate the effect of the water hyacinth cover on distribution of SRB in sediments of Lake Victoria.

\section{Materials and methods}

\section{Sampling procedures}

Three sampling stations were studied on the Tanzanian shores of Lake Victoria in East Africa. Station S1 (02 $30^{\prime} 37 \mathrm{~S}$ and $032^{\circ} 53^{\prime}$ 23E, $1229 \mathrm{~m}$ above sea level) was $2000 \mathrm{~m}$ offshore from the Mwaloni fish landing site. The station was in open waters with a water column depth of $8.5 \mathrm{~m}$. Station S2 (02 $30^{\prime} 29 \mathrm{~S}$ and $032^{\circ} 53^{\prime}$ 55E, $1202 \mathrm{~m}$ above sea level) with water column depth of $3.5 \mathrm{~m}$ was $100 \mathrm{~m}$ from the shoreline of Mwanza municipal centre. This station was heavily infested by a stationary water hyacinth and received wastes from nearby fish landing site and market. Station S3 $\left(02^{\circ} 30^{\prime}\right.$ $52 \mathrm{~S}$ and $032^{\circ} 53^{\prime} 44 \mathrm{E}, 1247 \mathrm{~m}$ above sea level) with water column depth of $4.6 \mathrm{~m}$ was located at the Mirongo River mouth.

Sediment samples were collected using a Peterson grab sampler. The samples were taken between 09:00 and 13:00 and transferred into sterile plastic sampling containers and stored in a cooled icebox. The samples were immediately transported to the laboratory and stored at $4^{\circ} \mathrm{C}$. The physical, chemical and biological characterisation of sediment was performed the following day after collection. Sampling was conducted monthly from May 1997 to September 1998. May and June sampling was conducted during the wet season while the July to September sampling was done during the dry season.

\section{Analysis of physico-chemical parameters}

Dissolved oxygen (DO) of the water column was determined on site using a potable oxygen-meter (YSI Model 57 Oxygen Meter). Surface light intensity at sampling stations was determined on site using a field Light meter (LI-COR model LI-189; Sensor LI-COR Quantum Q19195). Analysis of sediments for phosphate ( $\left.\mathrm{PO}_{4}-\mathrm{P}\right)$ and nitrate $\left(\mathrm{NO}_{3}-\mathrm{N}\right)$ was done as described by Parson's et al. (1989) and Standard Methods (1995). The turbidimetric method, a modification of the classical technique was used for the determination of the concentration of sulphate in water column and sediments (ASA, 1982; Standard Methods, 1995).

\section{Quantification of SRB in sediments}

Three-tube most-probable-number (MPN) counts were made in sediment samples with acetate, formate or lactate as growth substrates (Widdel and Bak, 1991; Teske et al., 1998). Triplicate MPN dilution series were inoculated with $1 \mathrm{~m} \ell$ of a 10 -fold diluted sediment homogenate, equivalent to $0.1 \mathrm{~m} \ell$ of sediment material, and subsequently diluted in nine 1:10 dilution steps. The medium for culture of SRB from freshwater was similar to that described by Widdel and Bak (1991). Strict anaerobic and aseptic conditions as described by Vester and Ingvorsen (1998) were maintained during the study by filling the headspace of culture tubes with nitrogen $\left(\mathrm{N}_{2}\right)$ gas. Deoxygenated solutions of culture media were supplemented with sodium salts of acetate, formate or lactate to provide final concentrations of $20 \mathrm{mM}$ acetate, $20 \mathrm{mM}$ formate, or $20 \mathrm{mM}$ lactate respectively.

\section{Preparation of MPN tubes and inoculation}

A volume of $15 \mathrm{~m} \ell$ of sulphate reducing medium was dispensed into narrow neck anaerobic culture tubes (16 by $150 \mathrm{~mm}$, Belco glass, Inc.) and sealed with n-butyl stoppers. The air in the culture tubes was evacuated several times and gassed with $\mathrm{N}_{2}$. The culture tubes were kept under a pressure head of 0.5 bar $\mathrm{N}_{2}$ and sterilised at $121^{\circ} \mathrm{C}$ for $20 \mathrm{~min}$ (Widdel and Bak, 1991). Inoculations were made with sterile $1.0 \mathrm{~m} \ell$ syringes. Triplicate MPN dilution series were inoculated by transferring $1.0 \mathrm{~m} \ell$ samples of the diluted sediment homogenates to the culture tubes, maintained under $\mathrm{O}_{2}$-free $\mathrm{N}_{2}$ head pressure and incubated at $30^{\circ} \mathrm{C}$ for not more than 6 weeks. Results were unaffected by longer incubation times. In each experiment, three un-inoculated tubes were included as controls. MPNs were scored positive when microbial growth, either as a turbid suspension or as bacterial clumps on the surface of the culture tube wall coincided with sulphide production determined by formation of black precipitation of ferrous sulphide (FeS). The distribution of FeS-positive and FeS-negative tubes was used to calculate the MPNs from appropriate probability tables (Jones and Paynter, 1980; Standard Methods, 1995). By this method, the amount of SRB in form of MPN/g wet sediment mass was obtained. Duplicate samples of primary sediment samples (1 g wet mass) were dried at $105^{\circ} \mathrm{C}$ to constant mass, and all SRB populations were expressed as MPN/g dry mass sediment (Jones and Paynter, 1980).

\section{MPN calculations and statistical analysis}

Most probable numbers (MPNs) were calculated according to the method of McCrady (Standard Methods, 1995). Following MPN determinations, statistical tests were carried out using INSTAT statistical software (1990-1993 GraphPad software V2.04, 931842B). Mean MPNs were calculated using one-way analysis of variance (ANOVA). Following ANOVA, differences in mean MPNs between stations were tested using Tukey-Kramer multiple comparison tests. All data were first tested for homogeneity of variances and normality using Bartlett's tests or Kruskal-Wallis non-parametric ANOVA followed by Dunn's multiple comparison tests. Correlation coefficients were used to determine the relationship between total numbers of SRB and nutrient concentrations in sediments. Overall mean SRB numbers were calculated from mean SRB for all the months from May to September for every station.

\section{Results}

Physico-chemical parameters of lake sediment and water column varied from station to station (Table 1). The concentration of $\mathrm{SO}_{4}-$ $\mathrm{S}$ in column and sediments varied from station to station and the difference in concentrations was highly significant among stations $(\mathrm{P}<0.0001)$. The concentration of sulphate in the column ranged from 4.77 to $37.68 \mathrm{mg} / \ell$ while in the sediments it ranged from 168.87 to $307.40 \mathrm{mg} / \mathrm{kg}$ dry mass sediment.

The SRB species that were found to be predominant in the 
water column and sediments of Lake Victoria along the shores of Mwanza Municipality morphologically and functionally highly resembled Desulfovibrio, Desulfobacter and Desulfococcus species. The difference in MPNs was highly significant $(\mathrm{P}<0.0001)$ among stations. The MPNs for acetate-utilising SRB were observed to be high in sediments from water hyacinth-infested stations (S2) and from the Mirongo River mouth station (S3) when compared to the open water station (S1) (Table 2).

The stations infested by the aquatic weed (S2) and the Mirongo River mouth station (S3) had a lot more formateutilising SRB, compared to the offshore and open water station (S1) (Table 3). Water hyacinth-infested station (S2) had a slightly higher mean population followed by the Mirongo River mouth station. The offshore and open water station (S1) had the lowest population of formate-utilising SRB.

The difference in bacteria counts was very significant among stations $(\mathrm{P}<0.0001)$ (Table 4). Lactate utilisers were the dominant $\mathrm{SRB}$ species in sediments at the water hyacinthinfested (S2) and the Mirongo River mouth (S2) stations while at the offshore open water station (S1), MPNs for lactate-utilising SRB were much lower than those for acetateand formate-utilising SRB. An increase in bacteria counts from May to September was observed at water hyacinthinfested (S2) and Mirongo River mouth (S3) stations. The highest population of lactate-utilising SRB was recorded at the Mirongo River mouth station (S3) and this was twice that observed at water hyacinth-infested station (S2). At the water hyacinth-infested (S2) and Mirongo River mouth (S3) stations, the numbers of lactate-utilising SRB increased from May to September unlike that at offshore open water station (S1).

In addition, SRB densities correlated positively with nutrients in the sediments. The highest positive correlation was that between $\mathrm{SRB}$ and $\mathrm{PO}_{4}-\mathrm{P}(\mathrm{r}=0.93)$ followed by that with $\mathrm{SO}_{4}-\mathrm{S}(\mathrm{r}=0.83)$ and lowest was that with $\mathrm{NO}_{3}-\mathrm{N}$ $(r=0.17)$.

\section{Discussion}

The SRB counts (MPNs) presented in this study are comparable with those reported in similar studies elsewhere. In a study on sulphate reduction in cyanobacterial mats of Solar Lake (Sinai, Egypt), Teske et al. (1998) reported acetate and lactate SRB utilisers in the range of $2.0 \times 10^{5}$ to $9.0 \times 10^{6}$ and $0.9 \times 10^{6}$ to $4.6 \times 10^{6}$ cells $/ \mathrm{m} \ell$, respectively, while the MPNs for formate-utilising SRB were similar to those of acetate utilisers. The dominance of lactate-utilising SRB at water hyacinth-infested (S2) and Mirongo River mouth (S3) stations also agreed with observations reported by Parkes et al. (1993). The high MPN values in sediments recorded at the Mirongo River mouth and water hyacinth-infested stations may be attributed to high inputs of organic material and the decaying weed (Gupta et al., 1997). The water hyacinth decomposed to lactate and the sewage outlet provided more of the nutrients necessary for the growth of the lactateutilising SRB. This led to the proliferation of the lactateutilising SRB at the water hyacinth-infested stations also receiving sewage outflow.

The increase in lactate-utilising SRB counts from May to September observed at the water hyacinth-infested station (S2) is probably attributed to stable anoxic sediment condi-

\begin{tabular}{|l|c|c|c|}
\hline \multicolumn{4}{|c|}{ TABLE 1 } \\
and sediments \\
Physico-chemical characteristics of water column \\
\hline Parameter & Station S1 & Station S2 & Station S3 \\
\hline sli $\left(\mu \mathrm{mol}\right.$ photons $\left./ \mathrm{M}^{2} \cdot \mathrm{S}^{1}\right)$ & $45.0 \pm 32.2$ & $11.6 \pm 9.3$ & $52.9 \pm 51.5$ \\
$\mathrm{DO}(\mathrm{mg} / \ell)$ & $5.9 \pm 0.7$ & $3.4 \pm 1.4$ & $6.1 \pm 0.5$ \\
$\mathrm{SO}_{4}-\mathrm{S}(\mathrm{mg} / \ell)$ & $4.8 \pm 0.26$ & $37.7 \pm 0.8$ & $17.3 \pm 1.2$ \\
$\mathrm{SO}_{4}-\mathrm{S}(\mathrm{mg} / \mathrm{kg}$ dry weight) & $168.9 \pm 12.9$ & $307.4 \pm 10.5$ & $212.3 \pm 19.0$ \\
$\mathrm{PO}_{4}-\mathrm{P}(\mathrm{mg} / \mathrm{kg}$ dry weight) & $3.3 \pm 3.0$ & $4.0 \pm 2.9$ & $5.5 \pm 4.1$ \\
\hline $\mathrm{n}=16 ; \mathrm{DO}=$ dissolved oxygen; sli = surface light intensity. \\
\hline
\end{tabular}

$\mathrm{n}=16 ; \mathrm{DO}=$ dissolved oxygen; sli = surface light intensity

\begin{tabular}{|c|c|c|c|}
\hline \multicolumn{4}{|c|}{$\begin{array}{l}\text { TABLE } 2 \\
\text { Population of acetate-utilising SRB (MPN/g dry weight) in } \\
\text { sediments }\end{array}$} \\
\hline $\begin{array}{l}\text { Sampling } \\
\text { time }\end{array}$ & Station S1 & Station S2 & Station S3 \\
\hline May & $(1.2 \pm 0.6) \times 10^{4}$ & $(1.7 \pm 1.3) \times 10^{6}$ & $(3.2 \pm 2.7) \times 10^{6}$ \\
\hline June & $(7.3 \pm 4.3) \times 10^{4}$ & $(2.8 \pm 2.9) \times 10^{6}$ & $(1.7 \pm 0.6) \times 10^{6}$ \\
\hline July & $(8.4 \pm 5.7) \times 10^{4}$ & $(2.5 \pm 0.0) \times 10^{6}$ & $(3.9 \pm 1.6) \times 10^{6}$ \\
\hline September & $(3.0 \pm 0.0) \times 10^{4}$ & $(3.4 \pm 1.7) \times 10^{6}$ & $(1.1 \pm 1.0) \times 10^{6}$ \\
\hline Mean population & $(5.0 \pm 3.5) \times 10^{4}$ & $(2.6 \pm 0.7) \times 10^{6}$ & $(2.5 \pm 1.3) \times 10^{6}$ \\
\hline
\end{tabular}

\begin{tabular}{|c|c|c|c|}
\hline \multicolumn{4}{|c|}{$\begin{array}{l}\text { TABLE } 3 \\
\text { Population of formate-utilising SRB (MPN/g dry weight) in } \\
\text { sediments }\end{array}$} \\
\hline $\begin{array}{l}\text { Sampling } \\
\text { time }\end{array}$ & Station S1 & Station S2 & Station S3 \\
\hline May & $(2.6 \pm 4.0) \times 10^{4}$ & $(1.1 \pm 1.2) \times 10^{6}$ & $(7.0 \pm 5.9) \times 10^{5}$ \\
\hline June & $(3.7 \pm 3.7) \times 10^{4}$ & $(8.7 \pm 1.4) \times 10^{6}$ & $(3.2 \pm 2.8) \times 10^{6}$ \\
\hline July & $(5.0 \pm 2.8) \times 10^{4}$ & $(4.7 \pm 2.0) \times 10^{6}$ & $(1.9 \pm 2.5) \times 10^{6}$ \\
\hline September & $(3.7 \pm 2.7) \times 10^{4}$ & $(3.8 \pm 1.9) \times 10^{6}$ & $(2.6 \pm 2.0) \times 10^{6}$ \\
\hline Mean population & $(3.8 \pm 1.0) \times 10^{4}$ & $(4.6 \pm 1.9) \times 10^{6}$ & $(2.1 \pm 1.1) \times 10^{6}$ \\
\hline
\end{tabular}

\begin{tabular}{|l|c|cc|}
\hline \multicolumn{4}{|c|}{ TABLE 4} \\
Population of lactate-utilising SRB (MPN/g dry weight) in \\
sediments
\end{tabular}




\begin{tabular}{|l|c|c|c|c|}
\hline \multicolumn{5}{|c|}{ TABLE 5 } \\
$\begin{array}{c}\text { Correlation between total numbers of SRB } \\
\text { and nutrients in sediments }\end{array}$ \\
\hline & SO $_{4}-\mathrm{S}$ & SRB & $\mathrm{NO}_{3}-\mathrm{N}$ & $\mathrm{PO}_{4}-\mathrm{P}$ \\
\hline $\mathrm{SO}_{4}-\mathrm{S}$ & 1.00 & 0.83 & 0.17 & 0.56 \\
$\mathrm{SRB}^{-}$ & 0.83 & 1.00 & 0.70 & 0.93 \\
$\mathrm{NO}_{3}-\mathrm{N}$ & 0.70 & 0.17 & 1.00 & -0.20 \\
$\mathrm{PO}_{4}-\mathrm{P}$ & 0.56 & 0.93 & -0.20 & 1.00 \\
\hline
\end{tabular}

tions caused by low water mixing which resulted from the thick water hyacinth mats covering water surface and climatic change from the rainy period (in May) towards the dry period (in September). During the rainy period, strong water waves as a result of strong winds cause the mixing of the water columns, which in turn oxygenate the sediments. This destabilised the anoxic conditions necessary for sulphate reduction (Teske et al., 1998; Wind et al., 1999). In the dry season, there was very little water mixing as the winds were weak, the water stratified and the sediments became more anoxic. The anoxic environment stabilised and enhanced the growth of SRB whose counts increase. This may explain the observed increase in bacteria counts from May to September at water hyacinth-infested (S2) and the Mirongo River mouth (S3) stations.

Surface light intensity at the water hyacinth-infested station (S2) may have also limited the growth of phototrophic SRB (Table 1) and possibly explains the slightly lower MPNs at this station than that recorded at the Mirongo River mouth station (S3). In offshore and open waters (S1), nutrients were limiting and probably explain the significantly low MPNs for SRB in these sediments. Holmer and Kristensen (1994) observed that an increase in organic matter enhanced $\mathrm{SO}_{4}^{2-}$ reduction and increased populations of SRB in sediments. The concentration of DO in Lake Victoria has been reported to be significantly decreasing as a result of human impacts resulting in deteriorated water quality (Bootsma and Hecky, 1993; Hecky et al., 1995; Ogutu-Ohwayo et al., 1997).

The strong positive correlation observed between populations of SRB and the nutrients suggest that these nutrients enhanced an increase in populations of these bacteria. Such a relationship between SRB populations and sulphate reduction activity in sediments has been reported by other workers (Parkes et al., 1993; Vester and Ingvorsen, 1998). The major source of $\mathrm{PO}_{4}^{-2}$ and $\mathrm{NO}_{3}$ ${ }^{1}$ is sewage and animal wastes and $\mathrm{SO}_{4}^{-2}$ may be present in domestic discharges including agro-industrial wastewaters and municipal sewage flowing into Lake Victoria. The relatively low levels of nutrients and MPNs for SRB observed in offshore and open waters (S1)compared to the other stations, may be due to the high dilution factor of lake water. Bootsma and Hecky (1993) noted that large dilution capacities and long flushing times of Lake Victoria are among the major factors, which make the detection of chemical pollutants in this lake very difficult.

In a study on SRB in marine and estuarine sediments, Parkes et al. (1993) observed that the distribution of different types of SRB broadly corresponded to the concentrations of substrates present. They observed that lactate-utilising SRB were dominant where lactate was the major substrate for sulphate reduction. In the present study, lactate-utilising SRB were dominant at the water hyacinth-infested shore station (S2) and the Mirongo River mouth station (S3) while a uniform distribution of acetate and formateutilising SRB was observed. The dominance of lactate-utilising
SRB at the water hyacinth-infested (S2) and the river mouth (S3) stations suggest an input of high concentrations of lactate into sediments at these stations. Lactate is reported to be incompletely fermented to acetate and propionate by some SRB species (Jones and Paynter, 1980; Parkes et al., 1993). Chocooj et al. (1993) in their investigations on the possibility of cultivating edible mushrooms (Pleurotus) on water hyacinth observed that this plant (water hyacinth) was cellulose-rich. Fermentation of cellulose from aquatic weeds by various anaerobic cellulose-degrading microorganisms produces lactate among other major products which are then utilised as growth substrates for SRB (Jones and Paynter, 1980; Parkes et al., 1993). The degradation of cellulose to lactate may be another likely explanation for the high MPNs of lactateutilising SRB recorded at the water hyacinth-infested shore and Mirongo River mouth stations.

Putrefaction and desulfurylation is the significant source of

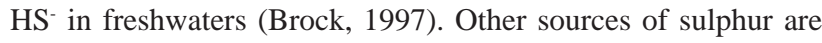
dimethyl sulphide $\left(\mathrm{H}_{3} \mathrm{C}-\mathrm{S}-\mathrm{CH}_{3}\right)$, methanethiol $\left(\mathrm{CH}_{3} \mathrm{SH}\right)$, and dimethyl disulphide $\left(\mathrm{H}_{3} \mathrm{C}-\mathrm{S}-\mathrm{S}-\mathrm{CH}_{3}\right)$. The sulphate produced in the water as a result of anaerobic microbial activity is then primarily reduced by SRB to hydrogen sulphide $\left(\mathrm{H}_{2} \mathrm{~S}\right)$. The form in which $\mathrm{H}_{2} \mathrm{~S}$ is present in the environment depends on $\mathrm{pH}$. At high $\mathrm{pH}$, the dominant form is sulphide ( $\left.\mathrm{S}^{2-}\right)$. At neutral $\mathrm{pH}$, HS- predominates, and at low $\mathrm{pH}, \mathrm{H}_{2} \mathrm{~S}$, a gaseous product, is the major species (Brock, 1997). In areas where the weed grows and the Mirongo River mouth, $\mathrm{pH}$ values were lower (Muyodi, 2000). The low $\mathrm{pH}$ values caused $\mathrm{H}_{2} \mathrm{~S}$ to exist in the gaseous form. The gaseous form of $\mathrm{H}_{2} \mathrm{~S}$ could be the cause of the foul smell and of coloured waters at these stations.

\section{Conclusions}

The water hyacinth has negative influence on the general quality of Lake Victoria. It facilitates proliferation of SRB, which produce by-products of metabolism, some of which are environmentally unfriendly. Decomposition of the water hyacinth produces lactate more than any of the other substrates (formate and acetate) which support the growth of lactate-utilising SRB species. Sewage outlets provide more nutrients that support the growth of the SRB under the water hyacinth, and also provide nutrients for the alien weed to prevail in the lake. The quality of the water column under the alien weed deteriorates significantly as more organic matter in the form of detritus is added as suspended solids. These make the water column turbid and foul smelling. The water hyacinth also serves as a habitat for various organisms (for example mosquitoes, snails and snakes); some of these are harmful to the well-being of man. An extensive study to characterise and identify the SRB species phylogenetically is highly recommended.

\section{Acknowledgement}

The authors wish to thank the Netherlands Universities Fund for International Corporation, "NUFFIC" for funding this project.

\section{References}

ASA (1982) Methods of Soil Analysis. Part 2. Chemical and Microbiological Properties ( ${ }^{\text {nd }}$ edn.) American Society of Agronomy, Madison, Wisconsin, USA.

BOOTSMA HA and HECKY RE (1993) Conservation of the African Great Lakes. Conserv. Biol. 7 644-656.

BROCK TD (1997) Prokaryotic diversity: Bacteria. In: Madigan MT, Martinko JM and Parker J (eds.) Biology of Microorganisms (8th edn.). Prentice-Hall International, Inc., New Jersey. 
CHOCOOJ DLR, SOTO-VELAZCO C, GUZMAN-DAVALOZ L and GUZMAN G (1993) Cultivation of Pleurotus on water hyacinth and determination of the heavy metals in Mexico. Mushroom Res. 237-40.

GUPTA MK, SHRIVASTAVA P and SINGHAL PK (1997) Decomposition of young water hyacinth leaves in lake water. Hydrobiol. 335 33-41.

HECKY RE, BUGENYI FWB, OCHUMBA P, TALLING JF, MUGIDDE R, GOPHEN M and KAUFMAN L (1995) Deoxygenation of the deep water of Lake Victoria, East Africa. Limnol. Oceanogr. 39 1476-1481.

HOLMER M and KRISTENSEN E (1994) Coexistence of sulphate reduction and methane production in an organic-rich sediment. Mar. Ecol. Progress Series 107 177-184.

IIORI MO, OKONKWO AM and BAMIDELE M (1999) Factors affecting growth of sulphate-reducing bacteria isolated from tropical soil. Zeitschrift für Naturforschung C. J. Biosci. 54 613-616.

JONES WJ and PAYNTER MJB (1980) Populations of methane-producing bacteria and in vitro methanogenesis in salt marsh and estuarine sediments. Appl. Environ. Microbiol. 39 864-871.

KANSIIME F and NALUBEGA M (1999) Wastewater Treatment by a Natural Wetland: The Nakivubo Swamp, Uganda. Processes and Implications. Ph.D. Thesis, Delft, The Netherlands.

KING GM and GARRY MA (1999) Ferric iron reduction by bacteria associated with the roots of freshwater and marine macrophytes. Appl. Environ. Microbiol. 65 4393-4398.

MERINYO GPM (1990) Urban waste disposal systems in Tanzania. Property Digest 11 18-22.

MINZ D, FISHBAIN S, GREEN SJ, MUYZER G, COHEN Y, RITTMANN BE and STAHL BA (1999) Unexpected population distribution in a microbial mat community: Sulphate-reducing bacteria localised to the highly oxic chemocline in contrast to eukaryotic preference to anoxia. Appl. Environ. Microbiol. 65 4659-4665.

MUYODI FJ (2000) Microbiological Analysis of the Waters of Lake Victoria in Relation to the Invasion of the Water Hyacinth, Eichhornia crassipes (Mart.) Solms. A Case Study of the Lakeshores of Mwanza Municipality. Ph.D. Thesis, University of Dar es Salaam, Tanzania. OGUTU-OHWAYO R, HECKY RE, COHEN AS and KAUFMAN L (1997) Human impacts on the African Great Lakes. Environ. Biol. Fish. 50 117-131.

PARKES RJ, DOWLING NJE, WHITE DC, HERBERT RA and GIBSON GR (1993) Characterisation of sulphate-reducing bacterial populations within marine and estuarine sediments with different rates of sulphate reduction. FEMS Microbiol. Ecol. 102 235-250.

PARSONS TR, MAITA Y and LALLI CM (1989) A Manual of Chemical and Biological Methods for Seawater Analysis. Pergamon Press, Oxford.

ROZANOVA EP and ENTALTSEVA LA (1999) Distribution of sulphatereducing bacteria in a hot water supply system and the origin of hydrogen sulphide in water. Microbiol. 68 85-90.

SCHONHEIT P, KRISTJANSSON JK and THAUER RK (1982) Kinetic mechanism for the ability of sulphate reducers to outcompete methanogens for acetate. Arch. Microbiol. 132 285-288.

STANDARD METHODS (1995) Standard Methods for Examination of Water and Wastewater (19 $9^{\text {th }}$ edn.) APHA, Washington DC.

TESKE A, RAMSING NB, HABICHT K, FUKUI M, KUVER J, JORGENSEN BB and KOHEN Y (1998) Sulphate-reducing bacteria and their activities in cyanobacterial mats of Solar Lake (Sinai, Egypt). Appl. Environ. Microbiol. 64 2943-2951.

VAN GEMERDEN H (1993) Microbial mats: A joint venture. Mar. Geol. 113 3-25.

VESTER F and INGVORSEN K (1998) Improved most-probable-number method to detect sulphate-reducing bacteria with natural media and a radiotracer. Appl. Environ. Microbiol. 64 1700-1707.

WIDDEL F and BAK F (1991) Gram-negative mesophyllic sulphatereducing bacteria. In: The Prokaryotes (Vol. 4) ( $2^{\text {nd }}$ edn). SpringerVerlag, New York.

WIND T, STUBNER S and CONRAD R (1999) Sulphate-reducing bacteria in rice field soil and on rice roots. System. Appl. Microbiol. 22 269-279. 
